\title{
MONITORING EROSION AND ACCRETION SITUATION IN THE COASTAL ZONE AT KIEN GIANG PROVINCE
}

\author{
Nguyen Thi Hong Diep ${ }^{1 *}$, Nguyen Tan Loi ${ }^{1}$, Nguyen Trong Can ${ }^{1}$ \\ ${ }^{1}$ Land Resources Department, College of Environment and Natural Resources, Can Tho University, Vietnam
}

KEY WORDS: erosion/accretion, Kien Giang province, Normalized Difference Water Index (NDWI), shoreline

\begin{abstract}
:
Kien Giang is one of the coastal provinces in the Mekong Delta which is facing the problem of coastal erosion to affect people's life in the coastal area. This project aims to monitor shoreline and to assess landslide and accretion situation in the period from 1975 to 2015 in the coastal area of Kien Giang province. The study applied Normalized Difference Water Index (MNWI) method and water level extraction using LANDSAT imagery from 1975 to 2015 for highlight the shoreline. Thus, analysis was identified erosion and accretion areas based on shoreline changes and land use influenced by landslides and deposition. The results show to create shoreline changes from 1997 to 2015 in the coastal area of Kien Giang province. A landslide occurred in the west from Nguyen Viet Khai commune to Thuan Hoa commune and Nam Yen commune to Vinh Hoa Hiep commune, Rach Gia city, Kien Giang province. An accretion situation was determined in the areas from Thuan Hoa commune, An Minh district to Nam Thai commune, An Bien district, Kien Giang province, Rach Gia sea encroachment at Rach Gia town and Ha Tien encroachment area at Ha Tien town, Kien Giang province. In general, the coastal area of Kien Giang province has a predominant tendency of accretion, however, the occurrence of erosion and accretion are happened interlacing in the coastal area at Kien Giang province.
\end{abstract}

\section{INTRODUCTION}

\subsection{Background}

The Mekong Delta and the Lower Mekong Basin are one of the seven major ecological areas of the Mekong River Basin in which a specific characterized terrain and diversity ecosystems (MRC-Mekong River Commission, 2010), to supply the most important food crop in the Southeast Asia and focusing on a world-class of biodiversity to be affected by human activities and subsidy issues and shoreline erosions (Edward J. Anthony et al., 2015). The coastal area of Kien Giang province is usually impacted by natural disasters of climate change and sea level rise, and the estimated sea level rise by 2100 is increasing to $100 \mathrm{~cm}$ (Carew-Reid, 2008). At present, coastal erosion and coastal protection forests in Kien Giang are serious changes (Duc Van, 2014). Kien Giang coastal is unstable and changes year by year with less accretion area, more erosion than deposition, and there are two shoreline areas increasing erosion (Ngo C. N. et al, 2014). Coastal erosion and sedimentation are the major concern in coastal management. Changes in morphology and location along the coast of Kien Giang have caused a major impact on land use and socio-economic development in coastal area (Nguyen Hai Hoa et al., 2010). Besides of these causes, endogenous factors such as impacts from stratigraphic change, flow, water level fluctuation, storm, wave and wind and exogenous factors caused by human impacts, thus coastal area monitoring is very necessary. Rapid appraisal methods are needed to update coastal maps of affected areas and to monitor shoreline change rate. There have currently no assessment of coastal shoreline dynamics, coastal vulnerability and mangrove functions that were conducted in Kien Giang province (Nguyen H.H.et al, 2010).
With the continuous development process of science and technology, the detection of coastal erosion or accretion areas are relatively implemented quickly and less expensive than conventional measurement methods and predicted areas where severe erosion or accretion to early warning (R. Kanan \& MV, 2016). The assessment of land use and the effective management of shoreline erosion are necessary because of the complicated developmental issues and detecting what is happen negatively to the coast. The research is implemented to detect shoreline changes and to assess coastal land use impacts in the western of Kien Giang province during 40 years using remote sensing and GIS technology, and support an effective solution to ensure for local development and shoreline changes to effect on natural environment as well as living condition in the coastal areas.

\subsection{Study area}

The focused area is the west sea which belongs to Kien Giang province. It is lain from 9023'50" to 10032 '30" North and $104^{\circ} 26^{\prime} 40$ - $105^{\circ} 32^{\prime} 40$ East with the coastline over 200 kilometers, and it is from Mui Nai (Ha Tien- Kien Giang) to An Minh province (Kien Giang). This is an area where complexed shoreline has been occurring with the processes of erosion and accretion. According to the Department of Agriculture and Rural Development, the coastlines Hon Dat - Kien Luong, An Minh - An Bien and some river mouths have extremely effects by erosion due to wave, strong wind in the monsoon season, and loss of mangrove forest (Figure 1). 


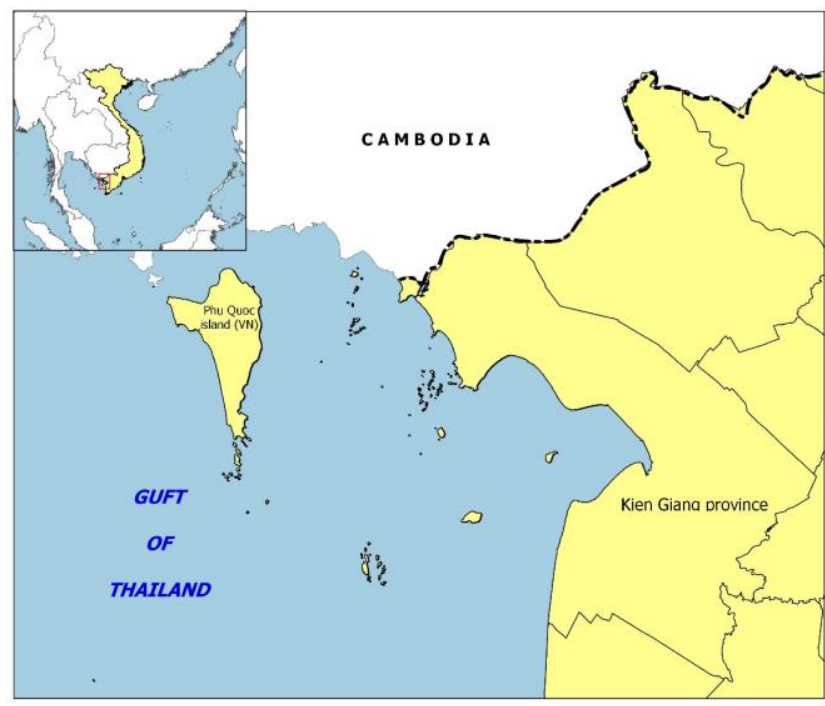

Figure 1. The research area in Kien Giang province

\section{METHODOLOGY}

\subsection{Data collection}

Remote sensing data using Landsat images were collected in each 5 years period including in 1975, 1990, 1995, 2000, 2005, 2010 and 2015 in the western coastal area of Kien Giang province on the website at http://earthexplorer.usgs.gov and https://libra.developmentseed.org.

Secondary data consist of the administration map in the Mekong Delta.

\subsection{Pre-processing imagery}

Geometric and atmospheric correction: Landsat images were used as the map projection and reference ellipsoid of WGS84, UTM Zone $48 \mathrm{~N}$.

Striped image correction: to solve this situation using the Gapfill tool using on the ERDAS software.

\subsection{Classification}

Image interpretation keys are based on eight factors: size, shape, shade, tone, color, texture, pattern and key combination (objects location on the image). The objects will be classified on the image in Kien Giang province including forest; forest and aquaculture; urban and accretion area.

Using specific band combination to identify accurately each object based on spectral characteristics.

\subsection{Creating water index (NDWI - Normalized Difference Water Index)}

The NDWI is a remote sensing based indicator sensitive to the change in the water content of leaves (Gao, 1996).

$$
\mathrm{NDWI}=(\mathrm{NIR}-\mathrm{SWIR}) /(\mathrm{NIR}+\mathrm{SWIR})
$$

Where NIR is Near-Infrared band and SWIR is Short Wave Infrared band.

\subsection{Shoreline extraction}

Based on wavelength spectrum on Landsat imagery, combining between image ratio and extraction of soil and water were developed shoreline quickly (Thao, P. T. P. et al., 2009). This method was highlight the land and water boundaries due to threshold value (Thuy, D. T. N., 2016). Water reflection is equal zero on infrared band and soil reflection value is usually higher than water reflection value (Pritam Chand and Prasenjit Acharya, 2010). Water is a strong absorb in near infrared spectrum (NIR band, 0.7-0.8 $\mu \mathrm{m}$ ) and effective detection of submerged surfaces, distinguished between dry and wet soils, supplying an information of coastal wetland (Van, TT, \& Binh, T. T, 2008)

The threshold value method was implemented on NDWI and ratio images. The highest and lowest threshold values are selected by zero on the ratio and NDWI images to convert water pixel value into 0 and non-pixel value by 1 . A new image was created by adding each value on two images overlapping that have been assigned threshold value on threshold value image where water contains value by 0 and other pixel values are equal to 1 or 2 . Continuing implement the threshold value again to create threshold value image with the lowest value is 1 and the maximum value is 2 .

NDWI separated soil and water objects and using ratio images to highlight shoreline as following formula:

$$
\text { Shoreline }=(\text { Green } / \text { NIR }) \times(\text { Green } / \text { SWIR }))+ \text { NDWI }
$$

Where NIR is Near-Infrared band, SWIR is Short Wave Infrared band and NDWI is water index.

\subsection{GIS method}

Shoreline data was transferred to ArcGIS software by semiautomatic digitizer to create shoreline maps and identify erosion and accretion area on land use in coastal area.

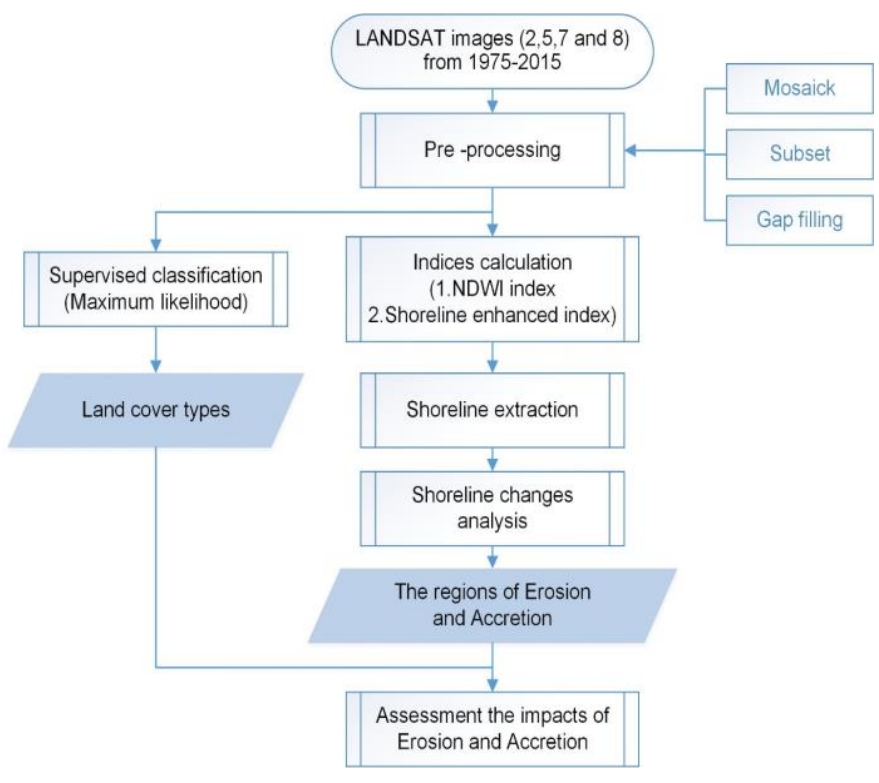

Figure 2. Flowchart of study area 


\section{RESULTS AND DISCUSSION}

\subsection{Erosion and accretion changes in the coastal zone of Kien Giang province from 1975 to 2015}

3.1.1 The shoreline changes from Thuan Hoa commune, An Minh district to Nam Thai commune, An Bien district, Kien Giang province

There is a curved coastline from Thuan Hoa commune, An Minh district to Nam Thai district, An Bien district thus erosion and accretion process are complicated in which accretion process is predominant. From 1975 to 1990 , total accretion area was 400.3 ha, total erosion area was 56.3 ha. In the period of 1990 to 1995 , the total area of sedimentation significant decreased at 56.5 ha and the total erosion area continuously decreased at 35.8 ha. From 1995 to 2000, the total area of accretion slightly decreased at 54.8 ha, however, the total area of erosion increased 54 ha. In the period of 2000 to 2005, the total accretion area slightly decreased at 44.9 ha and the erosion dramatically decreased at 12.5 ha. From 2005 to 2010, the total area of accretion was increasing by $95.6 \mathrm{ha}$, and total erosion area slightly increased by 14 ha. In the last period of 2010 to
2015, total deposition area and total erosion area continuously increased at 117.7 ha and 26.6 ha, respectively (Figure 3).

The accretion process in Nam Thai commune tends to increase and more increase than in Thuan Hoa commune. The erosion process tends to decrease instead of increasing of accretion process however it was complicated process. The reason is that topography in this area is overhanging on the sea thus an alluvial sediment is kept in Cai Lon estuary and gradually deposition to create an accretion area. In the west coast, shore area is affected by the tide of the west sea in the Gulf of Thailand that created Kien Giang coastal shape and tends to deposition in this area.

This is the erosion and accretion processes accumulation and effect mainly on forest and forest-aquaculture. Erosion process occurred in Thuan Hoa commune and accretion process was happened in Nam Thai commune. In the first stage of accretion process, deposition situation tended to decrease and then increase from 2000 to 2005 at 44.9 ha and adding more at 17.7 ha from 2010 to 2015 .
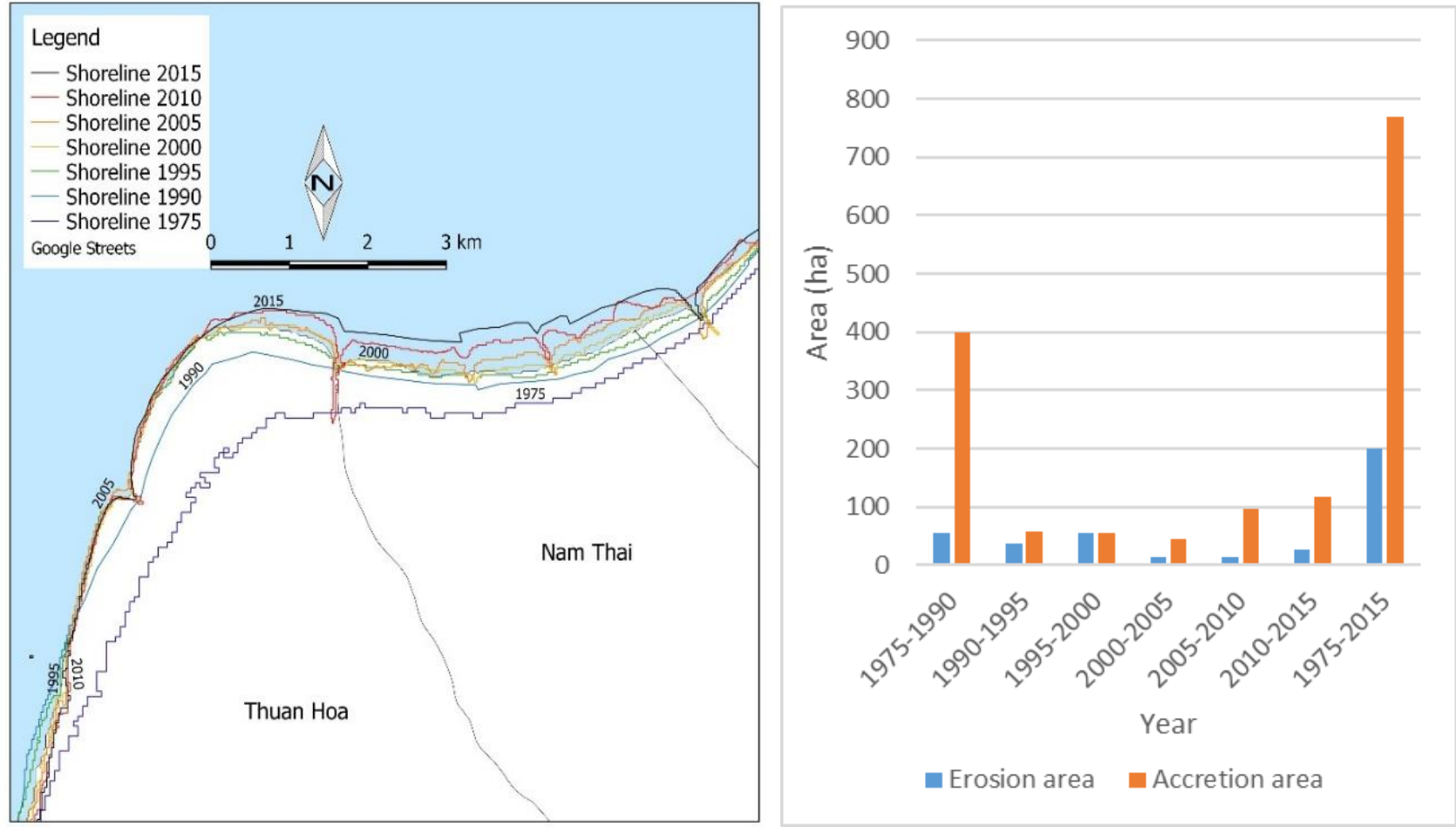

Figure 3. The shoreline processes from 1975 to 2015 in coastal areas from Thuan Hoa to Nam Thai commune, Kien Giang province

3.1.2 The shoreline changes from Tay Yen commune, An Bien district to Vinh Thanh Van commune, Rach Gia city

In this coastal area, erosion and accretion processes were also complicated in which deposition process is a main trend from Tay Yen commune, An Bien district to Vinh Thanh Van, Rach Gia city. From 1975 to 1990 , the total area of accretion was 253.5 ha and the total area of erosion was 123 ha. In the period of 1990 to 1995, the total area of accretion significant decreased at $65.6 \mathrm{ha}$, the total area of erosion continuously decreased at 54.6 ha. In the period of 1995 to 2000, total deposition area increase of $171.7 \mathrm{ha}$, however, total erosion area continued to decrease dramatically of 18 ha. From 2000 to 2005, total deposition area continuously increased to 178.6 ha and erosion area increased at 55.3 ha. In the period of 2005 to 2010 , the total area of accretion decreased up to $53.8 \mathrm{ha}$, total erosion area decreased to 28.4 ha. From 2010 to 2015, the total accretion area continued to decrease by 45.8 ha, however, the total area of erosion increased by 33.1 ha (Figure 4).

In this area, erosion process is complicated because Cai Lon river mouth is tending to the Gulf of Thailand and square root with the southwest monsoon, most of alluvial sediment from estuarine is flowed and transported out by the southwest wind 
into encroachment sea of Rach Gia city, thus a huge amount of alluvial sediment is not deposition in this area. Besides, the deforestation in protection forest has led to decrease forest density and strong influence of the southwest monsoon, the impact of strong waves and high tide cause to increase erosion in this area.

Coastal area from Tay Yen to Vinh Thanh Van communes has a complication of erosion and accretion process. The accretion situation is dominated in each period on three main of land used consist of forest, forest-aquaculture and urban area. The strong accretion stage was in two stages including the period from
1995 to 2000 at 171.1 ha and the period of 2000 to 2005 increase at 178.6 ha, because of the fast increase of urban area due to Rach Gia encroachment at Rach Gia City to be developed in 1999. In addition, the alluvium sediment in the Cai River is bringing to the encroachment and continuing deposition each year. However, wave and flow impacts and the other factors has lost some of land making erosion but have no serious. It is necessary to solve this issue such as dyke restoration and reforestation to keep alluvial sediment from river mouth.
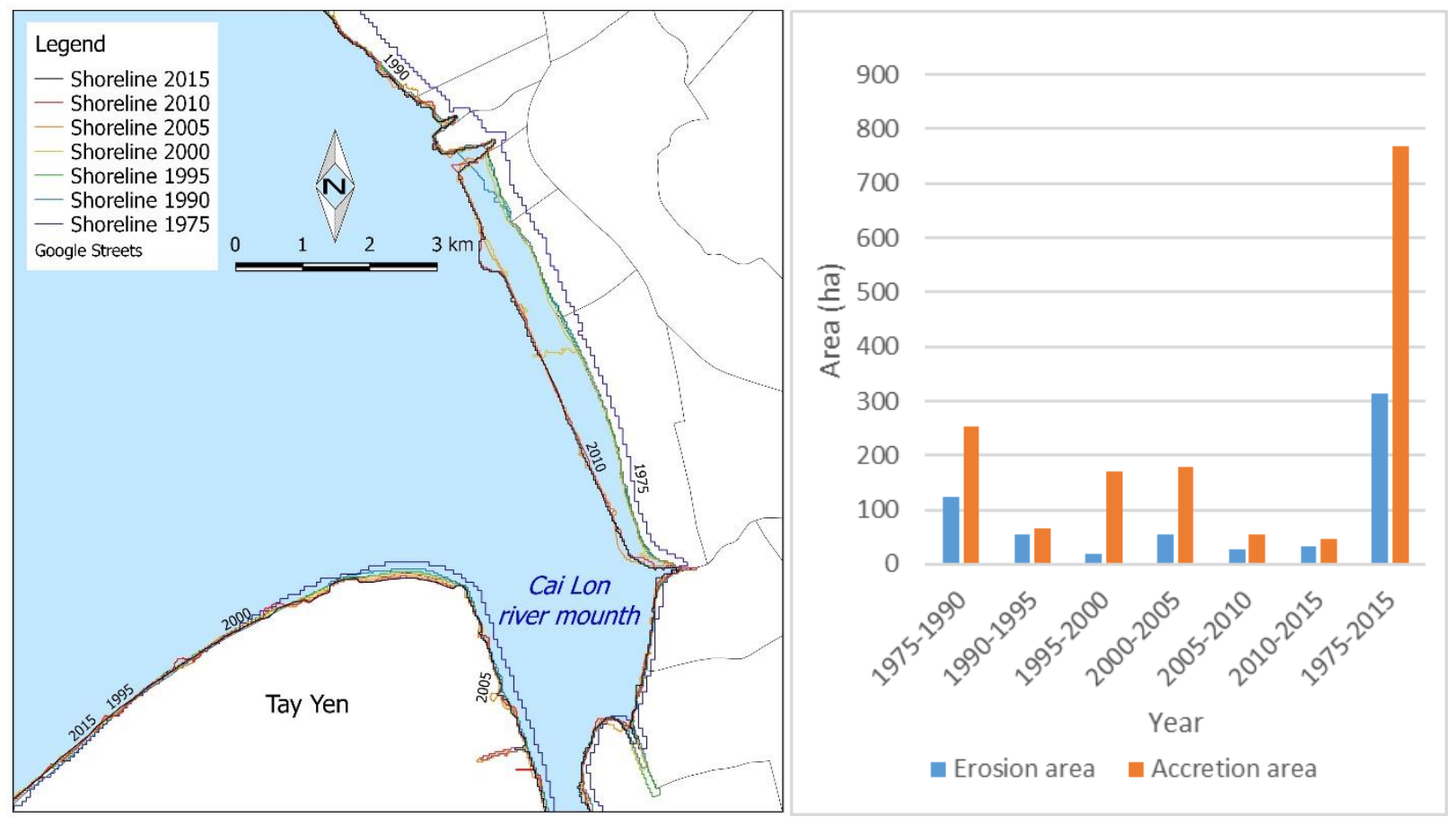

Figure 4. The shoreline changes in the period of 1975 to 2015 from Tay Yen to Vinh Thanh Van commune, Kien Giang province

3.1.3 The shoreline changes from Son Kien commune to Binh Son commune, Hon Dat district

The coastal area from Son Kien to Binh Son communes, Hon Dat district, Kien Giang province is about $37 \mathrm{~km}$ long with intermixed between erosion and accretion processes. From 1975 to 1990 , total accretion area was 834.7 hectares and total erosion area was 65.2 hectares. In the period of 1990 to 1995 , the accretion process significantly decreased with the total area of 88.6 ha, total erosion area decreased of 28.8 ha. In the period of 1995-2000, the total accretion area and total erosion area continuously decreased of 74.2 ha and 13.6 ha, respectively. From 2000 to 2005, the erosion process was more dominant than the accretion process, total area of sedimentation was 18 ha and erosion was 76 ha. In the period of 2005 to 2010, the accretion process increased with the total area of 87.5 hectares and the total area of erosion decreased of 32.9 hectares. From 2010 to 2015 , the accretion process slightly decreased with the total deposition area of 62.7 ha and the total area of erosion increase of 59.6 ha (Figure 5).

The direct influence of the southwest wind in summer was strongly impacted and the other effects due to the wind such as waves, flow, etc. in this area. Shoreline topography is mainly composed of rock which is large particles thus it is less washed away by the flow. Only abrasive and erosion for a long period due to the effect of natural factors cause of erosion issues. Besides, the policy of restoration of protection forest in 2005, the erosion has been reducing. This is the area of erosion and accretion intermixed processes in each period occurring at some locations in Binh Son commune. In the period of 2000 to 2005, the erosion was dominated with total erosion area of 76 ha on forest area of 49.2 ha and forest-aquaculture at 26.8 ha, extending from Son Kien to Binh Son commune, Hon Dat district. The accretion process was only 18 ha in which on the forest at 11.2 ha and on forest- aquaculture at 6.8 ha. 

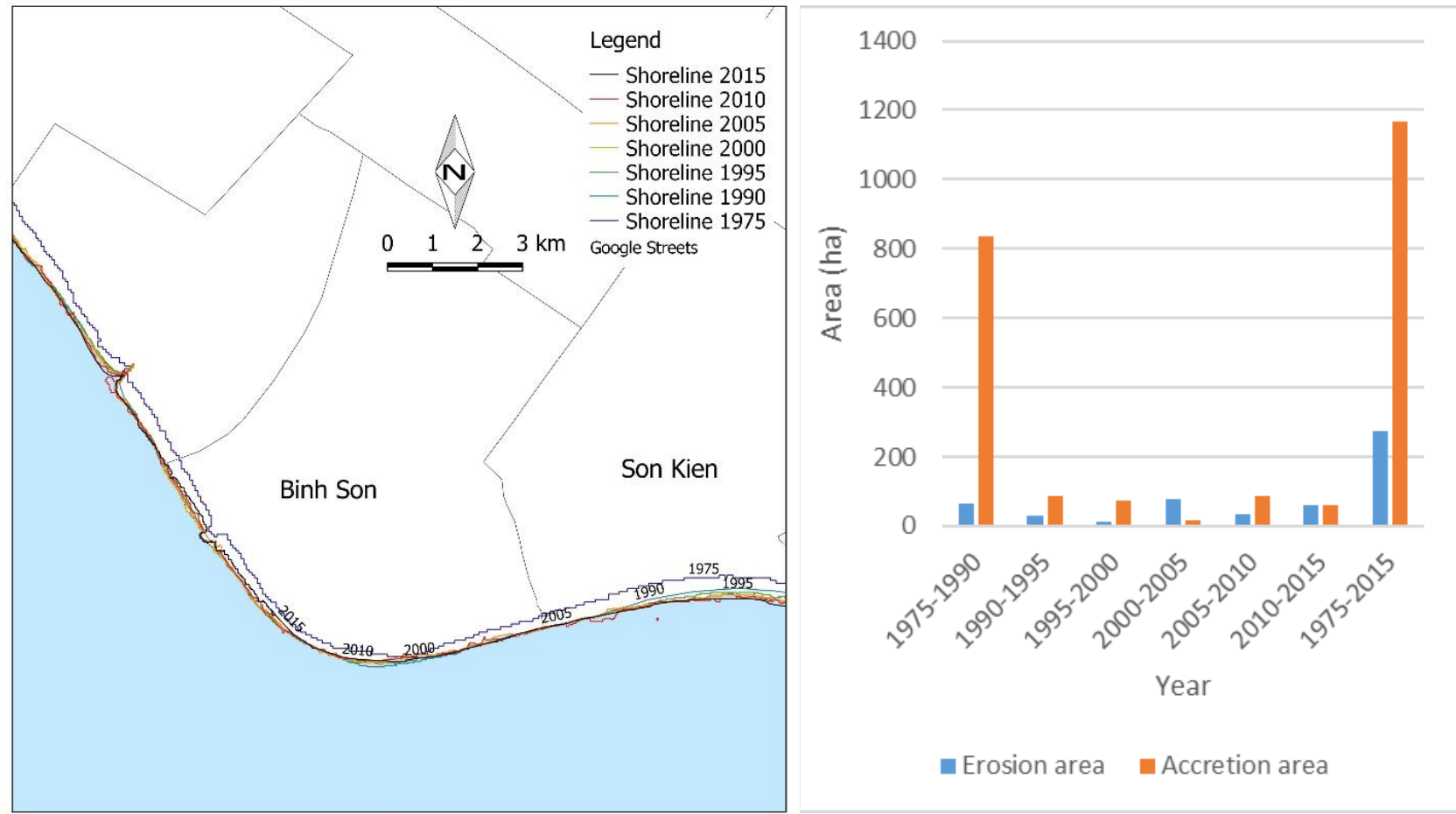

Figure 5. The shoreline changes from 1975 to 2015 in Son Kien to Binh Son commune, Hon Dat district, Kien Giang province

3.1.4 The shoreline changes form Ha Tien encroachment to Phao Dai commune, Ha Tien town

From 1975 to 1990 , the accretion process was dominant with the total area of 163.5 ha and the total erosion area was 91.4 ha. In the period of 1990 to 1995 , the erosion process was dominated with the total area of 42.3 ha, the total deposition area was decreased of 61.2 ha. In the period of 1995 to 2000, the accretion process continuously decreased with a total area of

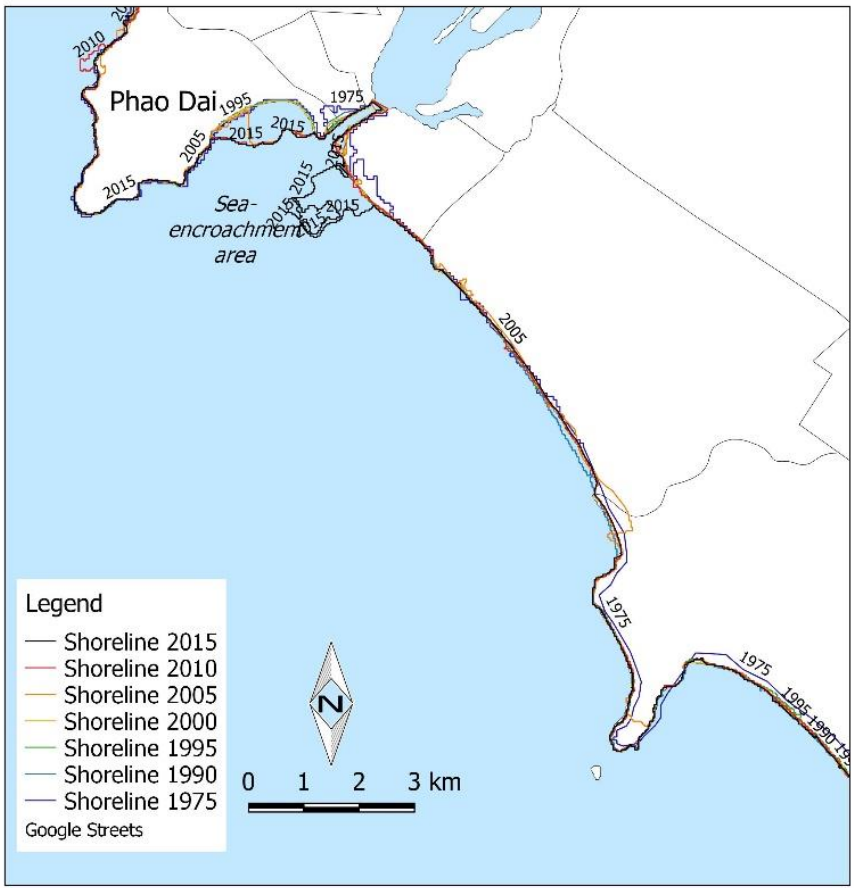

27.2 ha, total erosion area was significantly decrease to 8.4 ha. From 2000 to 2005, accretion process was more dominant than erosion, total area of sedimentation is 105.8 ha and erosion was 17.9 ha. In the period of 2005 to 2010, accretion process was slightly decrease with the total area of accretion of 89.4 ha, the total area of erosion was continuously of 14.5 ha. In the last period of 2010 to 2015 , the accretion process was slightly decreased to 81 ha, total erosion area increased at 18.9 ha (Figure 6).

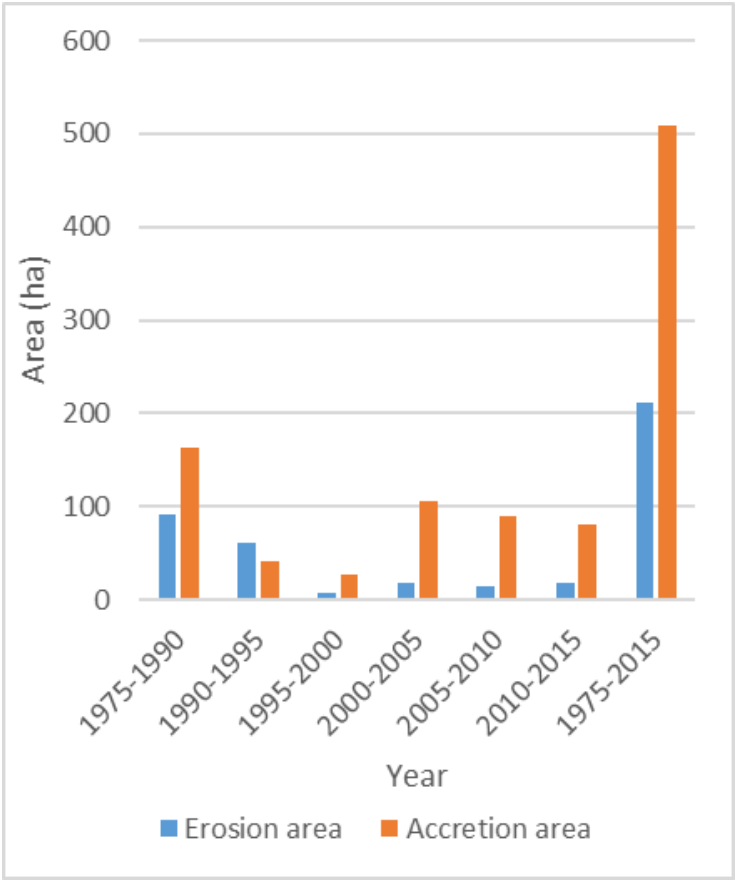

Figure 6. The shoreline processes in the period of 1975 to 2015 from Ha Tien encroachment to Phao Dai commune, Rach Gia city, Kien Giang province 
Due to sedimentation amount, coastal flow and the influence of the southwest wind each year, the accretion area increased significantly in Ha Tien encroachment. At the same time, the sea encroachment is concentrated thus the deposition trend is predominant. This area is avoided the northeast wind thus the amount of alluvial sediment lost due to the effect flow of the northeast wind is not significant. In general, Ha Tien encroachment area was developed, then deposition process was appearance, erosion and accretion processes are intermixed together. In the period of 1990 to 1995 , the erosion was predomination with a total area of 61.2 ha occurring mainly in the area of Phao Dai commune with an area of 42.3 ha. In the period of 2000 to 2005, Ha Tien encroachment was developed, the area of accretion increased sharply to $105 \mathrm{ha}$, then decreased gradually through the next period from 2010 to 2015 at 81 ha.

\subsection{Discussion of shoreline progress in the period of 1975 to} 2015

The erosion changes in the study area: total erosion area of 2,156.7 hectares, erosion processes increased sharply in the period of 1990 to 1995 of 511.3 hectares, then gradually decrease through the period from 1995 to 2010 and increase again in the period of 2010 to 2015 at 310 hectares. Total area of erosion is $1,326.6$ ha on forest-aquaculture of 748.8 ha and urban land of 81.3 ha.

The accretion changes in the study area: total area of accretion was 5,935.7 ha, accretion processes increased dramatically in the period of 1975 to1990 at 3,352.7 ha and from 1990 to 2000, the accretion area slightly decreased then gradually increase in which total accretion area on land use area at 3,474.2 ha in forest at 1,934.2 ha, forest and aquaculture at 599.1 ha and urban land at 599.1 ha.

The result in each period shows that coastline changes were changing in a complicated process to be divide into three processes: (1) typical accretion process, (2) typical erosion process and (3) the intermixed of accretion and erosion processes (Figure 7).
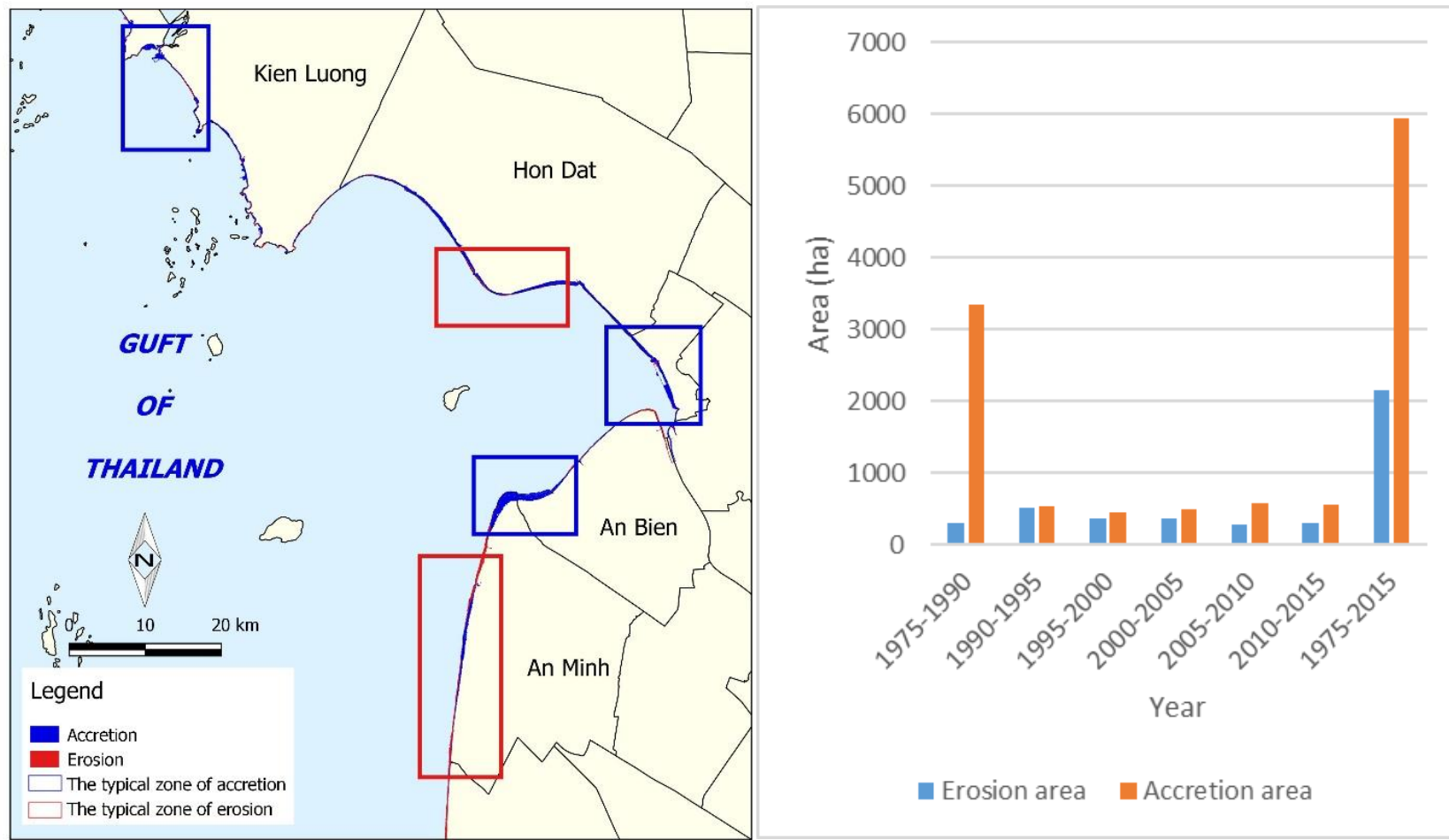

Figure 7. The typical accretion and erosion processes; intermixed of accretion and erosion processes in Kien Giang province from 1975 to 2015

Typical erosion area: from Nam Yen commune to Vinh Hoa Hiep commune, Rach Gia city, Kien Giang province.

Typical accretion area: from Rach Gia sea encroachment, Rach Gia city and Ha Tien sea encroachment, Ha Tien town, Kien Giang province.

The intermixed of sedimentation and erosion process areas: from Thuan Hoa commune, An Minh district to Nam Thai commune, An Bien district, Kien Giang province.

Due to the impact of global climate change, the coastal area of Kien Giang province in general will be impacted by the natural factors that causes of erosion and accretion processes to be happened with more complicated processes. The local government should be pay attention to the accretion and erosion processes and making decisions about those issues to solve the damage in the local coastal area.

\section{CONCLUSIONS AND RECOMMENDATIONS}

\subsection{Conclusion}

Applying the LANDSAT image from 1975 to 2015 and remote sensing technique, the shoreline changes maps was developed in Kien Giang province. 
Identification of coastal erosion and accretion has been described in detail through shoreline changes maps from remote sensing classification.

The coastline in the study area in a period of 1975 to 2015 was identified in a complicated processed and development in the general trend to the seashore.

The west coast is stable; which accretion process is more predominant than erosion.

\section{The erosion and accretion processes in Kien Giang province}

Typical erosion areas are consisting of Thuan Hoa commune, An Minh district, Kien Giang province, from Nam Yen commune area to Vinh Hoa Hiep commune, Rach Gia city, Kien Giang province.

Typical accretion areas are including from Thuan Hoa commune, An Minh district to Nam Thai commune, An Bien district, Kien Giang province, Rach Gia and Ha Tien sea encroachment area, Ha Tien town, Kien Giang province.

\subsection{Recommendations}

To apply the solution of dyke construction combined with mangrove reforestation for coastal protection.

Reforestation and restoration of coastal protection mangrove forest, managing and propagating the awareness of forest protection for local farmers in combination, pay attention and long-term protection in the coastal area.

\section{REFERENCES}

Carew-Reid, J. (2008). Rapid assessment of the extent and impact of sea level rise in Viet Nam, Climate Change Discussion Paper 1, ICEM - International Centre for Environmental Management, (February), 82.

Casse, C., Bach, P., Thi, P., Nhung, N., Phi, H., \& Dao, L. (2012). Remote sensing application for coastline detection in ca mau, Mekong Delta. Proceeding of International Conferance on Geometics for Spatial Infrastructure Development in Earth and Allied Science-GIS IDEAS.

Dang Thi Ngoc Thuy. (2016). Research on coastline changes in Phu Quoc Island from 1973 to 2010, 3(28), 64-69.

Edward J. Anthony, Guillaume Brunier, Manon Besset, Marc Goichot, P. D. \& V. L. N. (2015).

The relationship between erosion and human activities in the Mekong Delta. Science Journal, 2007. https://doi.org/10.1016/j.landusepol.2007.03.005

Gao, B., 1996. NDWI A Normalized Difference Water Index for Remote Sensing of Vegetation Liquid Water From Space. Remote Sensing of Environment, 58, 257-266

MRC-Mekong River Commission. (2010). State of the Basin Report 2010. Mekong River Commission. https://doi.org/ISSN 1728:3248
Ngo, C. N., Pham, T. H., Do, S. D., \& Nguyen, B. N. (2014). Status of coastal erosion of Vietnam and proposed measures for protection, 22.

Nguyen, H. H., Pullar, D., Duke, N., Mcalpine, C., \& Nguyen, H. T. (2010). Historic shoreline changes: an indicator of coastal vulnerability for human landuse and development in kien giang, vietnam. ACRS 2010: 31st Asian Conference on Remote Sensing, (December 2014), 1835-1843.

Nguyen, N. A. (2017). Historic drought and salinity intrusion in the Mekong Delta in 2016: Lessons learned and response solutions. Vietnam Journal of Science and Technology, 1(1), 2015-2018.

Pham Thi Phuong Thao, Ho Dinh Duan \& Dang Van To. (2009). Extracting the waterline from landsat images. Science \& Technology Development, Vol 12, No.12 - 2009

Pritam Chand, P. A. (2010). Shoreline change and sea level rise along coast of Bhitarkanika wildlife sanctuary, Orissa: An analytical approach of remote sensing and statistical techniques, $1(3), 436-455$.

R, K., \& MV, R. (2016). Shoreline Change Monitoring in Nellore Coast at East Coast Andhra Pradesh District Using Remote Sensing and GIS. Journal of Fisheries \& Livestock Production, 4(1). https://doi.org/10.4172/2332-2608.1000161

Van, T. T., \& Binh, T. T. (2008). Shoreline change detection to serve sustainable management of coastal zone in Cuu Long estuary, $1-6$ 